\title{
MUSEUM GARIS WAKTU TERUMBU KARANG
}

\author{
Carolina Tedjapranata ${ }^{1)}$ \\ 1) Program Studi S1 Arsitektur, Fakultas Teknik, Universitas Tarumanagara, \\ carolina.315170059@stu.untar.ac.id
}

Masuk: 02-07-2021, revisi: 09-08-2021, diterima untuk diterbitkan: 23-10-2021

\begin{abstract}
Abstrak
Perubahan iklim menyebabkan terjadinya pemanasan global di bumi. Peristiwa ini diawali dengan dimulainya Revolusi Industri, sebuah peralihan proses produksi dari tenaga manusia ke sistem mekanis yang mendorong pembangunan pabrik-pabrik dan juga sistem transportasi untuk mendukung distribusi barang-barang hasil produksi. Hal ini tentunya meningkatkan gas emisi karbon di udara. Daerah pesisir adalah daerah yang paling rentan terkena dampak negatif perubahan iklim. Naiknya temperatur bumi berdampak juga pada kenaikan temperatur perairan. Terumbu karang merupakan ekosistem perairan yang terkena dampak dari perubahan iklim. Kondisi terumbu karang kian memburuk seiring dengan naiknya temperatur bumi dan dapat menyebabkan kematian. Hal ini tidak hanya berpengaruh pada manusia, tetapi juga biota laut. Gili Matra adalah kawasan destinasi wisata diving dan snorkeling yang kaya akan terumbu karang. Didukung dengan adanya pembangunan kebun karang oleh pemerintah di Gili Meno sangat cocok dengan tujuan dari proyek ini. Dengan melalui metode eksperimental dan penggunaan teknologi membangun proyek "Museum Garis Waktu Terumbu Karang", proyek ini bertujuan untuk edukasi, pemeliharaan, dan penelitian terumbu karang, serta dipamerkan sebagai objek wisata untuk menarik wisatawan dan masyarakat, yang diharapkan mampu meningkatkan kesadaran masyarakat dan mempertahankan ekosistem laut, sehingga dapat memberikan sumbangan atau upaya dalam melestarikan terumbu karang, sekaligus memberikan edukasi kepada masyarakat atau wisatawan untuk mengenal kekayaan terumbu karang di Indonesia.
\end{abstract}

\section{Kata kunci: Gili Meno; Museum; Terumbu Karang}

\begin{abstract}
Climate change causes global warming on earth. This event was preceded by the start of the Industrial Revolution, a shift in the production system from human power to machine power, which encouraged the construction of factories and the transportation system to support manufactured goods. This thing increases the carbon emission gas in the air. Coastal areas are the regions generally defenseless against the adverse consequences of climate change. Coral reefs are oceanic environments that are influenced by environmental change. The condition of coral reefs is getting worse along with the earth's rising temperature and can cause death. This cause affects not only humans but also marine life. Gili Matra is a diving and snorkeling tourism destination that is rich in coral reefs. Supported by the development of a coral garden by the government in Gili Meno fits perfectly with the purpose of this project. By using experimental methods and the technology to build the "Museum of Coral Reef Timeline" project, this project aims to educate, maintain, and research coral reefs that are exhibited as tourist objects to attract tourists and the public, which are expected to increase public awareness and maintain the marine ecosystem, so that it can contribute or make efforts in conserving coral reefs, as well as providing education to the public or tourists to know the richness of coral reefs in Indonesia.
\end{abstract}

\section{Keywords: Coral Reefs; Gili Meno; Museum}




\section{PENDAHULUAN}

\section{Latar Belakang}

Perubahan iklim atau climate change sudah bukan topik asing lagi di telinga karena sudah menjadi masalah global yang sedang dihadapi dunia saat ini. Isu ini menjadi sangat penting sejak Earth Summit yang digelar di Brasil pada tahun 1992. Awal munculnya masalah iklim ditandai dengan Revolusi Industri, pergeseran sistem produksi energi manusia atau hewan menjadi mesin yang mendorong pembangunan pabrik-pabrik dan juga sistem transportasi untuk mendukung kegiatan distribusi barang-barang hasil produksi. Hal ini tentunya meningkatkan gas emisi karbon di udara. Perubahan iklim ditandai dengan naiknya permukaan air laut, peningkatan suhu bumi akibat gas rumah kaca (GRK), kekeringan, dan lainnya.

IPCC (2007) menujukkan bahwa daerah pesisir adalah daerah yang paling rentan terkena dampak negatif perubahan iklim, karena daerah pesisir merupakan zona transisi perubahan iklim, ekosistem laut dan daratan saling mempengaruhi (Dahuri dkk, 2001). Tanda-tanda perubahan iklim yang mengancam garis pantai adalah peningkatan yang signifikan dalam konsentrasi gas rumah kaca, kenaikan temperatur permukaan air, dan kenaikan permukaan laut (Aldrian dkk, 2001).

Menurut IPCC, suhu rata-rata meningkat $0,2^{\circ} \mathrm{C}$ setiap sepuluh tahun, dengan ambang batas mencapai $2^{\circ} \mathrm{C}$ lebih tinggi dari tingkat pra-industri pada tahun 2050 kemungkinan karena tingkat emisi gas rumah kaca. Bukti terbaru menunjukkan bahwa perubahan yang lebih cepat tidak hanya akan sangat mempengaruhi manusia, tetapi juga spesies dan ekosistem (Elizabeth dkk, 2010). Gas rumah kaca (GRK) disebabkan oleh aktivitas manusia yang menghasilkan polusi gas $\mathrm{CO}_{2}, \mathrm{CH}_{4}, \mathrm{CFC}, \mathrm{O}_{3}$, dan $\mathrm{N}_{2} \mathrm{O}$. Peningkatan suhu di bumi tidak hanya berdampak pada daratan, tetapi juga perairan. Hal ini tentunya sangat berkaitan dengan Indonesia sebagai negara maritim yang memiliki kekuatan besar di bidang kelautan dan perlu dikembangkan dan dikelola.

Menurut LIPI (2018), Indonesia memiliki luas 3.257.483 kilometer persegi, garis pantai 99.093 kilometer persegi, dan 13.466 pulau. Ada banyak ekosistem terumbu karang di sepanjang pantai dan di sekitar pulau-pulau yang memiliki banyak peranan, tetapi dapat berubah. Menurut citra satelit, luas terumbu karang di Indonesia diperkirakan 2,5 juta hektar. Namun, status terumbu karang di Indonesia semakin mendapat perhatian, terutama di provinsi Nusa Tenggara Barat yang termasuk ke dalam wilayah The Coral Triangle, yang ditetapkan WWF sebagai kawasan maritim yang dikonservasikan. Dampak dari pemanasan global mempengaruhi kondisi terumbu karang di Indonesia karena suhu perairan meningkat dan menyebabkan terjadinya pemutihan (bleaching) pada terumbu karang yang dapat mengakibatkan kematian dan berefek pada ekosistem laut. Menurut hasil penelitian yang dilakukan oleh Setiawan, Muttaqin, dkk. (2017), wilayah di Indonesia dengan tingkat persentase pemutihan terumbu karang cukup tinggi, yaitu sebesar 50\% adalah TWP Gili Matra.

\section{Rumusan Permasalahan}

Pada penelitian ini, penulis mengajukan pertanyaan tentang bagaimana cara merestorasi terumbu karang menggunakan struktur dan teknologi agar dapat menyeimbangkan ekosistem perairan laut sebagai bentuk melampaui ekologi dalam ketahanan terhadap pemanasan global dan juga pencemaran air oleh limbah.

\section{Tujuan}

Tujuan penelitian ini dilakukan untuk dapat meningkatkan kesadaran masyarakat dan mempertahankan ekosistem laut, sehingga dapat memberikan sumbangan atau upaya dalam melestarikan terumbu karang, sekaligus memberikan edukasi kepada masyarakat atau wisatawan untuk mengenal kekayaan terumbu karang di Indonesia. 


\section{KAJIAN LITERATUR}

\section{Perubahan Iklim}

Kementerian Lingkungan Hidup (2001) mengartikan perubahan iklim sebagai perubahan keadaan fisik atmosfer bumi yang berdampak besar pada semua bidang kehidupan manusia. Perubahan iklim mengacu pada perubahan kondisi iklim rata-rata suatu wilayah atau perubahan yang signifikan secara statistik dalam jangka waktu yang lama (biasanya beberapa dekade atau lebih) (IPCC, 2001). Ini juga menjelaskan bahwa perubahan iklim mungkin merupakan hasil dari proses alam internal atau eksternal atau aktivitas manusia yang terus-menerus mengubah struktur atmosfer dan penggunaan lahan.

\section{Gas Rumah Kaca}

Gas rumah kaca (GRK) ialah berbagai gas yang menyebabkan terperangkapnya sinar matahari yang seharusnya dipantulkan kembali oleh bumi. Semakin meningkatnya konsentrasi gas rumah kaca di atmosfer, semakin banyak sinar matahari yang diperangkap yang menyebabkan peningkatan suhu atmosfer.

\section{Pemanasan Global}

Peningkatan temperatur pemukaan bumi akan menyebabkan rusaknya mekanisme ekosistem dan biota bumi. Suhu merupakan salah satu parameter iklim, sehingga ketika suhu global berubah, perubahan iklim global yang ekstrim juga akan terjadi.

Indonesia merupakan negara maritim yang rentan terhadap dampak perubahan iklim. Antara tahun 1997 dan 1998, perubahan karakteristik El Niño akibat pemanasan global menyebabkan kebakaran hutan dan kerusakan parah pada terumbu karang di Indonesia (Wahyono, 2011).

Perairan Indonesia dengan luas $\mathbf{1 7 \%}$ dari total wilayah laut dunia memiliki kemampuan untuk menyerap gas karbon dioksida karena produktivitas primernya yang tinggi (Behrenfeld dkk., 2005). Produktivitas primer dapat berasal dari tumbuhan besar (lamun) dan tumbuhan air kecil (rumput laut, fitoplankton) (Astriyana dan Yuliana, 2012).

\section{Anomali Suhu Udara}

Anomali suhu udara tahunan ialah rasio temperatur udara pada tahun tertentu dengan rata-rata periode normal (1981 hingga 2010). Menurut 84 stasiun pengamatan BMKG, suhu rata-rata pada bulan Januari 2021 adalah $26.5^{\circ} \mathrm{C}$. Suhu rata-rata pada Januari 2021 ialah $0.1^{\circ} \mathrm{C}$ yang merupakan anomali positif. Pada bulan Januari 2021 ini tercatat sebagai anomali tertinggi ke-19 dari tahun 1981 hingga 2021. Sementara itu, temperatur rata-rata di tahun 2020 adalah $27.3^{\circ} \mathrm{C}$. Selama periode pengamatan tahun 1981 hingga 2020, 2016 tercatat sebagai tahun terpanas di Indonesia (nilai anomali $0.8^{\circ} \mathrm{C}$ ). Urutan kedua tahun terpanas ditempati oleh tahun 2020 dengan nilai anomali sebesar $0.7^{\circ} \mathrm{C}$. Disusul di urutan ketiga adalah tahun 2019 (nilai anomali $0.6^{\circ} \mathrm{C}$ ). Sebagai perbandingan, temperatur rata-rata global yang dipublikasikan dalam laporan terbaru World Meteorological Organization (WMO) pada awal Desember 2020 juga mencantumkan 2016 sebagai tahun terpanas (peringkat satu), dan 2020 sedang memasuki satu dari tiga tahun terpanas dalam sejarah.

\section{Terumbu Karang}

Ekosistem laut tropis yang berada di perairan yang jernih dan dangkal, dengan suhu di atas $22^{\circ} \mathrm{C}$, dan memiliki kandungan kalsium karbonat yang tinggi adalah terumbu karang (coral reefs). Terumbu karang memiliki komunitas yang didominasi oleh berbagai macam hewan karang keras (Guilcher, 1988). Terumbu karang berasal dari kata 'terumbu', yang memiliki arti punggungan laut yang dibentuk oleh batuan gamping di perairan dangkal dan 'karang', yang berarti struktur di dasar laut berupa endapan kalsium karbonat yang dihasilkan oleh hewan karang (Zurba, 2019). Karang dapat disebut juga sebagai karang batu (stony coral) dan tersusun atas puluhan atau jutaan polip. 
Biota laut menggunakan terumbu karang sebagai daerah untuk mencari makan, perawatan, dan tempat berlindung. Terumbu karang dimanfaatkan oleh masyarakat sebagai sumber protein, tempat memancing, bahan bangunan, tempat wisata, oleh-oleh, dan obat-obatan.

Dalam beberapa dekade terakhir, sistem terumbu karang telah terdegradasi dan rusak parah (Wilkinson, 2004; De'ath dkk, 2012; Hughes dkk, 2017). Hal ini disebabkan oleh beberapa faktor antropogenik, seperti:

a. Penangkapan ikan secara besar-besaran

b. Meningkatnya jumlah turis dan pengembangan di wilayah pesisir

c. Meningkatnya limbah

Menurut Veron (2000), laju pertumbuhan karang dapat dipengaruhi beberapa faktor, yaitu temperatur, salinitas, kecepatan arus, kecerahan, serta cahaya.

\section{Kondisi Terumbu Karang}

Sebuah studi oleh The Nature Conservancy dan United Nations Environment Programme (UNEP) memperkirakan bahwa pada tahun 2050, 90\% terumbu karang dunia akan hilang. Laporan khusus IPCC memperkirakan bahwa pada tahun 2100 , pemanasan global dengan $1,5^{\circ} \mathrm{C}$ akan menurunkan permukaan air laut global sebesar $10 \mathrm{~cm}$, dan meningkatkan suhu sebesar $2^{\circ} \mathrm{C}$, serta menurunkan $70-90 \%$ jumlah terumbu karang.

Seperti enam negara lainnya yang terletak dalam segitiga karang dunia, Indonesia termasuk ke dalam salah satu negara dengan keberagaman hayati karang terkaya di dunia dengan berbagai macam tumbuhan dan hewan laut. Lebih dari 480 spesies terumbu karang telah diidentifikasi di Indonesia bagian timur, dan $60 \%$ di antaranya adalah spesies terumbu karang dunia telah dipaparkan (Burke, 2002).

Secara umum, penelitian Pusat Penelitian Oseanografi Lembaga IImu Pengetahuan Indonesia (Hadi, Giyanto, et al., 2018) menunjukkan bahwa dibandingkan tahun sebelumnya, status terumbu karang saat ini di Indonesia telah berubah. Ada 386 site yang masuk ke dalam kategori jelek (36.18\%), 366 site masuk ke dalam kategori cukup (34.3\%), 245 site masuk ke dalam kategori baik (22.96\%), dan sebanyak 70 site masuk ke katogori sangat baik (6.56\%).

\section{Pemutihan Karang}

Fenomena yang sangat populer, yaitu pemanasan global yang merusak terumbu karang dan disebut sebagai pemutihan karang atau coral bleaching. Pemutihan karang adalah peristiwa yang merusak hubungan simbiosis antara karang dan alga yang bersimbiosis di dalam karang. Sebuah studi oleh Fine dkk. (2002), menyatakan bahwa pemutihan karang terjadi di seluruh dunia pada tahun 2000 menyebabkan kematian dan kerusakan ekosistem terumbu karang. Hal ini menarik perhatian para ilmuwan dan manajer sumber daya, sehingga mereka berspekulasi tentang masa depan terumbu karang ketika suhu laut meningkat akibat pemanasan global.

\section{Ekologi}

Seorang peneliti asal Jerman bernama Ernst Haeckel mengatakan bahwa ekologi adalah ilmu kompleks yang mempelajari hubungan antara organisme dan lingkungan (Winarno, 1992).

\section{Beyond Ecology}

Melalui paparan kuliah yang dibawakan Agustinus (2021), ada enam acuan bekerja dalam berarsitektur menuju "beyond ecology", diantaranya adalah:

1. Energy and Emission

Kemampuan untuk menerapkan zero $\mathrm{CO}_{2}$ emission dalam pengoperasionalan bangunan dan meminimalisirkan efek karbon dalam material dan konstruksi. 


\section{Adaptation}

Kemampuan untuk melakukan riset dan desain yang berkaitan dengan berbagai dampak, seperti naiknya suhu bumi, naiknya permukaan laut, kekeringan, banjir, kelangkaan pangan, perubahan populasi.

\section{Resilience}

Kemampuan untuk membangun kelanjutan 'hunian' dan pemulihan cepat setelah kejadian guncangan, bencana alam, gangguan listrik atau iklim.

\section{Sustainable Digital}

Kemampuan untuk melihat data-data lingkungan sebagai Big Data dalam menentukan taktik dan strategi dalam membangun kualitas spasial.

\section{New Technology}

Kemampuan memanfaatkan teknologi terbaru untuk meningkatkan kualitas dan terapan ruangkonstruksi dan program bangunan.

\section{Context}

Kemampuan dalam melihat posisi 'tempat' dalam hubungan dengan lingkungan (flora-fauna, biotik-abiotik) di mana sebuah konfigurasi keruangan akan ditempatkan.

\section{METODE}

Penulis menggunakan jenis penelitian dengan data kualitatif dan berbagai metode digunakan dalam tahap perancangan. Metode yang digunakan untuk mengumpulkan data lokasi tapak ialah melalui data sekunder yang diambil secara daring, platform Youtube, jurnal, dan juga ebook. Adanya keterbatasan dalam pengambilan data secara primer (observasi) dikarenakan kondisi pandemi global yang terjadi di Indonesia.

Program-program yang diusulkan menggunakan teori dari William Pena, yang kemudian dianalisis dan disusun dalam sebuah tabel, sehingga terumuskan program-program yang sesuai untuk merespon isu yang diangkat.

Metode yang dilakukan untuk pembentukan massa menggunakan metode arsitektur naratif dari film Aquaman. Dari hasil analisis film tersebut, gubahan massa diolah kembali dan disesuaikan dengan kondisi tapak dan lingkungannya untuk membentuk massa bangunan, seperti yang dapat dilihat pada gambar 1.

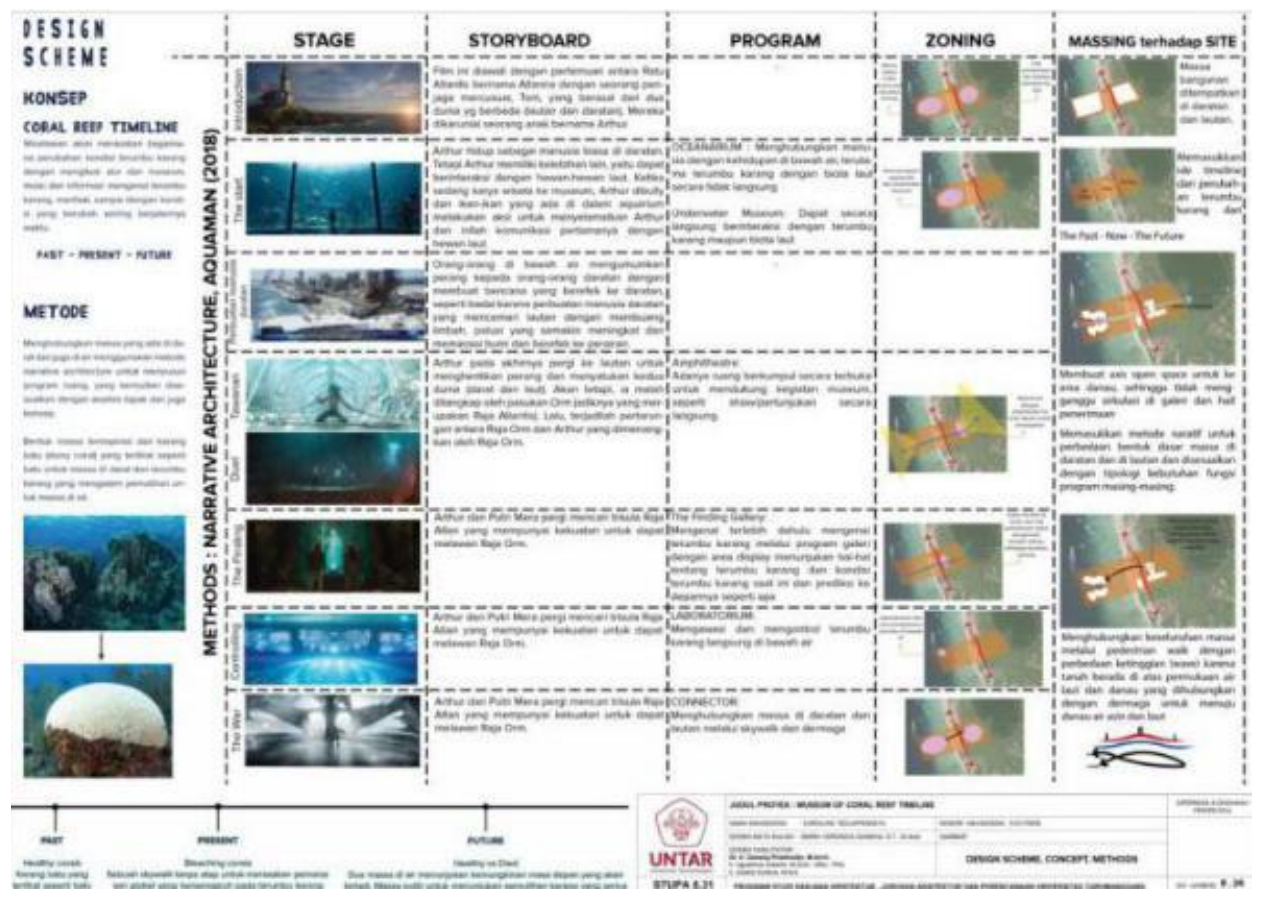

Gambar 1. Skema Desain

Sumber: Penulis, 2021 


\section{DISKUSI DAN HASIL}

\section{Ekosistem Terumbu Karang}

Permukaan bumi tertutupi oleh air lebih dari 71 persen dan 97 persennya berbentuk air laut. Air berperan sangat penting untuk seluruh kehidupan yang ada di bumi. Perairan erat kaitannya dengan kehidupan bawah laut, terutama terumbu karang dan kehidupan di dalamnya.

Terumbu karang ialah salah satu sumber daya laut yang memiliki manfaat besar bagi manusia dan lingkungan. Ekosistem terumbu karang ini memiliki banyak fungsi dan manfaat, seperti ekonomi, ekologi, dan sosial budaya. Produktivitas ekosistem terumbu karang menempati urutan ketiga setelah bakau dan alga. Terumbu karang sama menariknya dengan hutan hujan tropis karena keanekaragaman hayati, estetika, dan fungsinya.

Indonesia ialah salah satu negara di dalam kawasan "The Coral Triangle" dan memiliki banyak terumbu karang. Perubahan iklim mempengaruhi kondisi terumbu karang yang ada. Akibat pemanasan global yang terjadi, suhu di perairan meningkat dan menyebabkan pemutihan di beberapa wilayah. Pemutihan tidak berarti mati, akan tetapi secara perlahan dapat mati. Tentunya hal ini dapat mengganggu ekosistem bawah air.

\section{Mengembalikan Ekosistem Terumbu Karang}

Salah satu upaya untuk memulihkan ekosistem terumbu karang adalah dengan merestorasinya. SER (2004) mendefinisikan restorasi sebagai sebuah "proses membantu memulihkan ekosistem yang telah terdegradasi, hancur, atau rusak." Juga, "restorasi dilakukan sebagai upaya untuk mengembalikan ekosistem ke lintasan sejarahnya". Rehabilitasi menekankan "perbaikan proses ekosistem, produktivitas, dan jasa," tetapi hal ini tidak berarti dapat kembali ke kondisi biotik yang sudah ada sebelumnya. Ekosistem mengandung sumber daya alam. Ada cukup faktor biotik dan abiotik untuk melanjutkan pembangunan tanpa bantuan atau subsidi lebih lanjut (semua definisi dari Kelompok Kerja Sains \& Kebijakan Internasional Masyarakat untuk Restorasi Ekologi, 2004). Mengikuti definisi ini, membangun pembibitan karang bukanlah proyek restorasi itu sendiri, tetapi sebagai alat untuk restorasi.

\section{Biorock Technology as Coral Reefs Restoration}

Teknologi biorock merupakan salah satu cara yang dapat diterapkan untuk merestorasi terumbu karang. Di Indonesia, Biorock Indonesia (BI) sudah menerapkan teknologi ini di beberapa provinsi, yaitu Bali, Sulawesi Utara, Maluku, NTB, NTT, dan DKI Jakarta.

Menurut beberapa penelitian yang dilakukan, terumbu karang biorock telah terbukti efektif di seluruh dunia dalam menciptakan habitat baru bagi kehidupan laut yang sebelumnya telah dirusak, ataupun tidak ada. Meskipun biorock secara tidak langsung tidak mungkin dapat memulihkan ekologi semua terumbu karang yang rusak di dunia, tetapi dengan dedikasi yang cukup adalah mungkin untuk membantu memperbaiki ekologi lokasi terumbu tertentu di berbagai titik di sepanjang jalur terumbu yang dipilih.

Menurut Biorock Indonesia (BI), biorock adalah gabungan dari dua kata, yaitu "bio" dalam bahasa Yunani, yang berarti kehidupan dan "rock" dalam bahasa Inggris yang berarti batu. Secara sederhana, biorock dapat diartikan sebagai batu dengan unsur hayati. Ada perbedaan dalam pengertian biorock dan teknologi biorock, yaitu istilah biorock mengacu pada batu yang terbentuk menggunakan teknologi biorock, sedangkan teknologi biorock mengacu pada proses pembentukannya.

Teknologi biorock menggunakan arus yang sangat rendah dan aman untuk memperluas dan memperbaiki struktur laut dengan skala apapun secara cepat. Diagram prinsip kerja teknologi biorock dapat dilihat pada Gambar 2. 


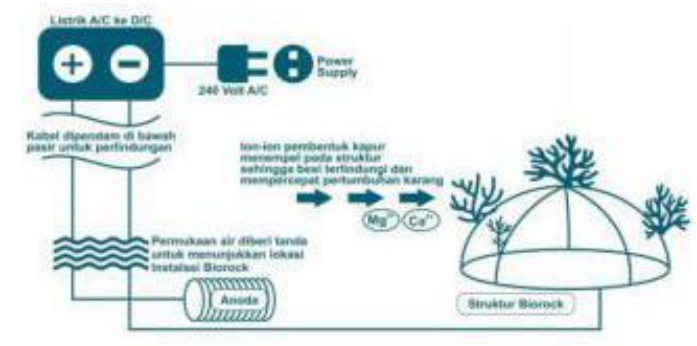

Gambar 2. Diagram Prinsip Kerja Teknologi Biorock

Sumber: Biorock Indonesia, 2020

Terumbu yang dipelihara secara ekologis akan berdampak positif pada kawasan terumbu di sekitarnya melalui peningkatan kesehatan dan kelimpahan terumbu karang di lokasi tersebut melalui program biorock, yang akan mengakibatkan peningkatan perekrutan larva karang ke kawasan tersebut dan peningkatan kelangsungan hidup karang muda, serta ikan di lokasi tersebut. Tidak seperti terumbu buatan yang terbuat dari bahan buatan, proses biorock merangsang pertumbuhan karang dan menghasilkan bahan batu kapur alami yang membentuk terumbu karang, tempat organisme terumbu lebih suka menetap.

\section{Tahapan-tahapan Restorasi}

Tahapan dalam restorasi dibagi menjadi tiga fase:

a. Fase 1 : Mendata wilayah-wilayah dengan kondisi terumbu karang yang mengalami pemutihan.

b. Fase 2 : Menerapkan teknologi biorock terhadap wilayah-wilayah yang terknea pemutihan, sehingga dapat sehat kembali dalam jangka waktu yang lebih pendek dibandingkan reproduksi terumbu karang asli.

c. Fase 3 : Pengawasan dan pengontrolan secara berkala; dapat dimanfaatkan sebagai sarana rekreasi dengan pengawasan ketat.

\section{Analisis Lokasi}

Lokasi proyek berada di NTB, khususnya di Taman Wisata Perairan (TWP) Gili Matra. Alasan pemilihan lokasi ini berdasarkan hasil penelitian Setiawan, Muttaqin, dkk. (2017), yaitu kerusakan terumbu karang akibat pemutihan di daerah ini relatif tinggi dengan komposisi kelompok karang yang mengalami pemutihan sebesar $50 \%$, pucat (18\%), mati (1\%), dan tidak terdampak 31\%. Pemutihan pada terumbu karang disebabkan oleh pemanasan global, sehingga temperatur air laut meningkat.

Pemutihan karang telah sering kali terjadi di Lombok, Selat Bali, dan Alas. Pemutihan karang terjadi di area barat Coral Triangle Area (CTA). Pemutihan karang ini mengakibatkan kematian karang skala besar di Selat Lombok untuk keempat kalinya, terutama di Gili Matra dan Sekotong. Menurut hasil penelitian oleh Kartawijaya dkk., (2012) responden yang bekerja di industri pariwisata menyatakan bahwa wisatawan dari TWP Gili Matra biasanya melakukan wisata bahari, terutama di kawasan terumbu karang, seperti scuba diving, snorkeling, penjelajahan hutan bakau, menyaksikan penyu, sunbathing, berenang, berkunjung ke taman burung, dan menjelajahi danau air asin. Dapat dilihat pada gambar 3, hubungan tapak dan lingkungan sekitarnya, terutama objek wisata yang ada di Gili Meno.

Pemilihan tapak berada di Pulau Gili Meno didukung dengan pemulihan pariwisata bahari dan ekosistem oleh KKP yang bekerja sama dengan Bank Indonesia cabang NTB dengan mendirikan kebun karang di perairan Lombok Utara, NTB.

Dalam pemilihan tapak, terdapat beberapa pertimbangan, yaitu:

a. Berada di kawasan wisata diving/snorkeling yang menjadi tujuan wisatawan. 
b. Memiliki terumbu karang yang melimpah dalam kondisi baik, maupun buruk, yang dapat dimanfaatkan sebagai daya tarik penelitian dan edukasi.

Detail besar tapak rancangan dapat dilihat pada gambar 4.

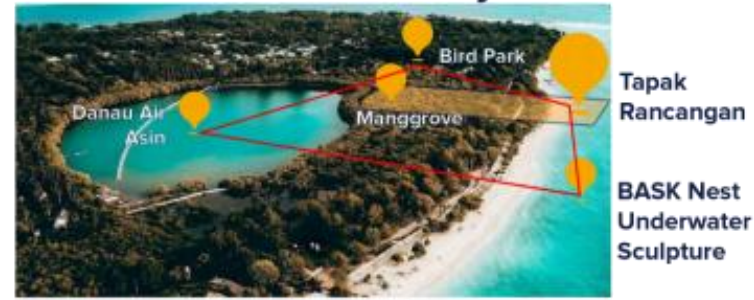

Gambar 3. Hubungan Tapak dengan Sarana Pariwisata Lainnya Sumber: Penulis, 2021

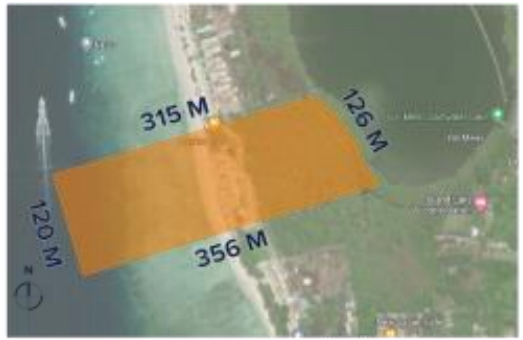

Gambar 4. Tapak Rancangan Sumber: Penulis, 2021

\section{Analisis Program}

Analisis program yang dilakukan menggunakan teori dari buku William Pena (1995) yang diolah dalam tabel 1.

\section{Tabel 1 Tabel Analisis Problem Seeking}

Sumber: Penulis, 2021

\begin{tabular}{lllll}
\hline & Goals & \multicolumn{2}{c}{ Facts } & Concept \\
\hline Function & Merestorasi terumbu karang & Masih banyak perilaku & Merancang sebuah wadah \\
(People, & dengan meningkatkan & masyarakat yang merusak edukasi untuk masyarakat \\
Activities, & kesadaran akan pentingnya & terumbu karang terutama sekitar, maupun wisatawan \\
Relationships) & terumbu karang sebagai & oleh limbah, polusi, dan mengenai terumbu karang \\
& ekosistem perairan & kegiatan lainnya (sektor agar ikut melestarikan & \\
& & pariwisata, seperti diving dan terumbu karang.
\end{tabular}

\begin{tabular}{ll}
\hline Form & Pemanfaatan lahan terumbu \\
(Site, & karang yang mengalami \\
Environment, & pemutihan di area \\
Quality) & konservasi yang ditetapkan \\
& KKP, dan juga berada di area \\
& wisata bawah laut untuk \\
& target pengunjung \\
& wisatawan lokal maupun \\
& mancanegara.
\end{tabular}

Pemutihan terumbu karang yang disebabkan pemanasan global dan limbah padat dan cair berdampak pada biota laut.

1. Merancang area wisata yang terkoneksi dengan area konservasi terumbu karang dan menjadi daya tarik proyek yang akan dirancang dengan target wisatawan.

2. Menghubungkan perairan dan daratan sebagai area perancangan

3. Dibutuhkan area penelitian untuk merestorasi terumbu karang yang rusak

\begin{tabular}{|c|c|c|c|}
\hline $\begin{array}{l}\text { Economy } \\
\text { (Initial Budget, } \\
\text { Operating } \\
\text { Costs, Life Cycle } \\
\text { Costs) }\end{array}$ & $\begin{array}{l}\text { Menjadi sumber pemasukan } \\
\text { ekonomi tambahan bagi } \\
\text { masyarakat sekitar dengan } \\
\text { daya tarik dari area } \\
\text { pariwisata, serta edukasi ini. }\end{array}$ & $\begin{array}{l}\text { Ada objek wisata lainnya di } \\
\text { daratan dan wisata bahari } \\
\text { yang luas di sekitar tapak } \\
\text { perancangan }\end{array}$ & $\begin{array}{l}\text { Terhubung ke sarana-sarana } \\
\text { lain yang ada di sekitar tapak. }\end{array}$ \\
\hline $\begin{array}{l}\text { Time } \\
\text { (Past, Present, } \\
\text { Future) }\end{array}$ & $\begin{array}{l}\text { Future: } \\
\text { 1. Menjadi katalisator untuk } \\
\text { konservasi terumbu karang } \\
\text { di wilayah lain untuk ke } \\
\text { depannya. } \\
\text { 2. Ekosistem terumbu karang } \\
\text { dalam keadaan kategori baik } \\
\text { yang menjadi tempat tinggal } \\
\text { bagi biota laut dan juga } \\
\text { dapat bermanfaat bagi } \\
\text { manusia }\end{array}$ & $\begin{array}{l}\text { 1. Past : Terumbu karang } \\
\text { Indonesia menempati } \\
\text { peringkat teratas dunia } \\
\text { untuk luas dan kekayaan } \\
\text { jenisnya. Lebih dari } 75.000 \\
\mathrm{~km}^{2} \text { atau sebesar } 14 \% \text { dari } \\
\text { luas total terumbu karang } \\
\text { dunia. } \\
\text { 2. Present: Kondisi terumbu } \\
\text { karang di Indonsia } \\
\text { mengalami kerusakan yang } \\
\text { parah }\end{array}$ & $\begin{array}{l}\text { Ekowisata dan edukasi } \\
\text { terumbu karang menjadi salah } \\
\text { satu konsep perancangan yang } \\
\text { dapat diterapkan, serta } \\
\text { kebutuhan penelitian dan riset } \\
\text { diperlukan untuk } \\
\text { keberlangsungan kondisi } \\
\text { terumbu karang ke depannya }\end{array}$ \\
\hline
\end{tabular}




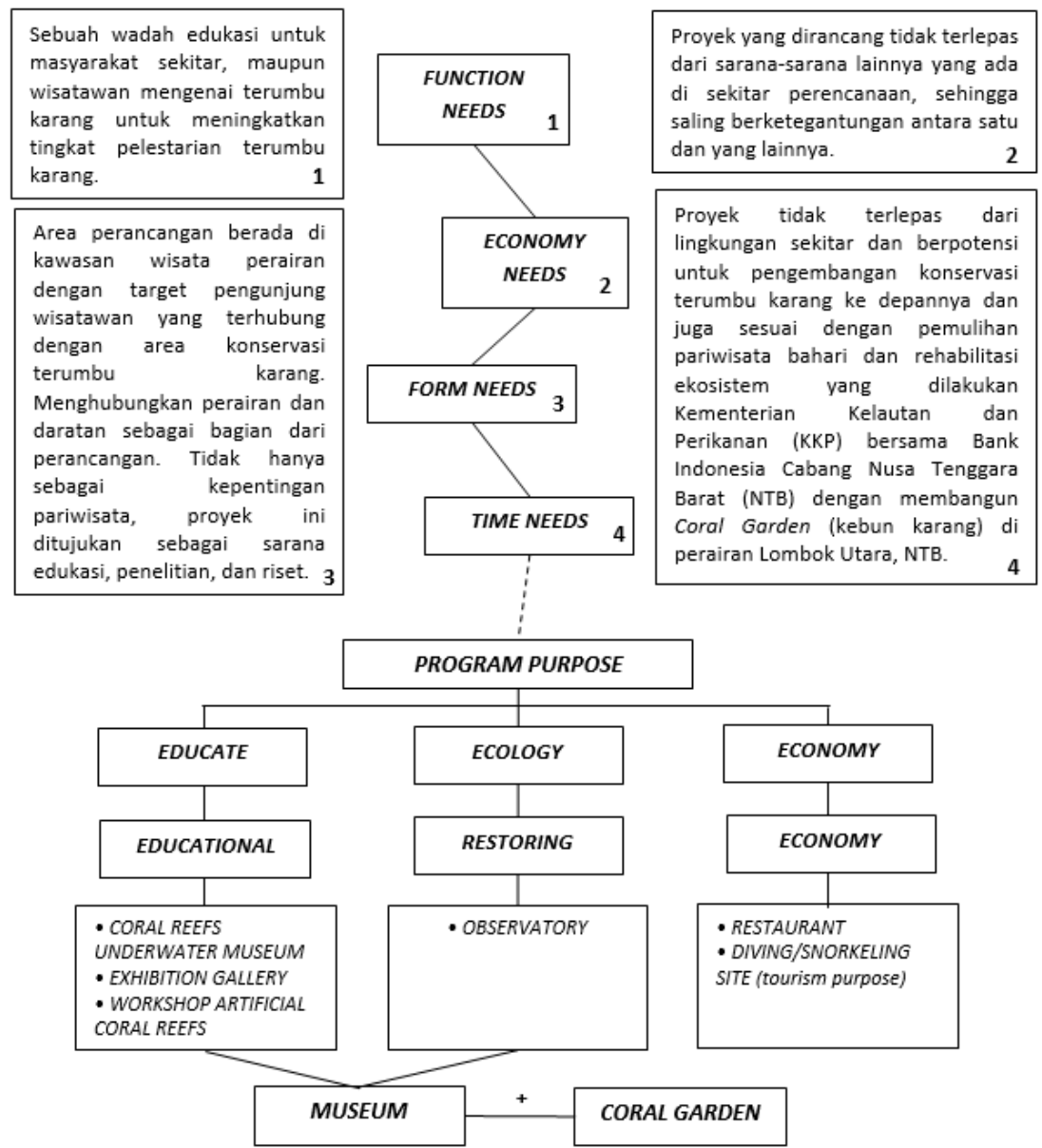

Gambar 5. Diagram Analisis Problem Seeking William Pena Sumber: Penulis, 2021

Dari tabel 1 kemudian dianalisis kembali, sehingga dihasilkan diagram analisis seperti pada gambar 5. Program yang diusulkan bertujuan unduk edukasi kepada para pengunjung dengan target wisatawan domestik dan asing, untuk lebih memahami terumbu karang, sehingga ikut merasakan bagaimana pentingnya terumbu karang dan juga bagaimana bahayanya bila terumbu karang rusak, bahkan sampai mati. Perlu adanya juga pusat penelitian terumbu karang untuk meneliti, dan bagaimana dapat merestorasi terumbu karang agar dapat kembali sehat. Perlu adanya pengecekan secara berkala, sehingga pusat penelitian ini diperlukan untuk menjaga kualitas/kesehatan terumbu karang. Jadi, tujuan proyek ini tidak hanya jangka pendek, tetapi juga tujuan kesehatan terumbu karang jangka panjang.

\section{Konsep dan Bentuk Rancangan}

Pembentukan massa didasari oleh perjalanan waktu (timeline) dari terumbu karang, yaitu pastnow-future, yang terbagi menjadi massa di daratan dan di lautan. Terumbu karang berperan sangat penting pada ekosistem di laut. Berikut adalah konsep pemecahan massa berdasarkan timeline terumbu karang:

Past : Massa penerimaan berada di daratan dengan bentuk massa menyerupai batu karang yang ada di pantai, tempat biota laut tinggal dan mencari makan. Program yang diusulkan berupa kantor, perpustakaan, ruang audio visual, dan galeri ekshibisi pengenalan, manfaat, dan contoh-contoh kerajinan yang dihasilkan terumbu karang.

Now : Kondisi terumbu karang sekarang mengalami pemutihan yang diakibatkan pemanasan global, sehingga diimplementasikan sebagai skywalk penghubung antara massa di daratan dan 
di perairan, tanpa atap. Jembatan penghubung ini dapat memberikan pengalaman ruang seperti seberapa panas matahari yang diterima oleh terumbu karang di perairan.

Future : Diimplementasikan menjadi dua buah massa, yang menunjukan bahwa masa depan terumbu karang dapat terjadi menjadi dua kondisi, yaitu kondisi terumbu karang yang baik seperti semula, atau semakin buruk dan pada akhirnya mati akibat pemutihan, seperti beberapa kasus yang sudah terjadi di Great Barrier Reef, Australia. Program dirancang untuk menjadi sarana pembelajaran melalui pameran terumbu karang dan laboratorium restorasi terumbu karang buatan yang dapat dilihat langsung maupun tidak langsung oleh pengunjung.

Setelah membagi massa, pembentukan massa disesuaikan dengan analisis tapak dengan alam sekitar yang dilakukan untuk membuka view corridor dari arah danau menuju laut, sehingga antara laut, pantai, daratan, dan danau saling terikat satu dengan yang lainnya dan memberikan pandangan bebas. Proses gubahan massa dapat dilihat pada gambar 6 .

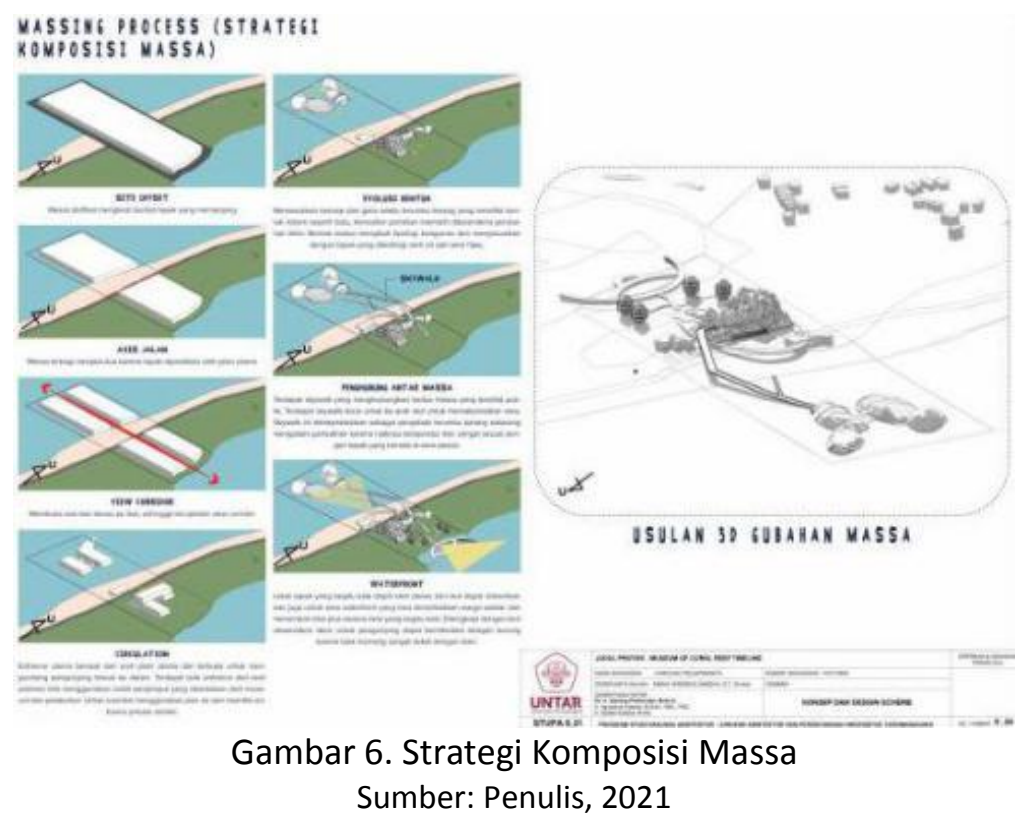

\section{Beyond Ecology Parameter}

Proyek yang dirancang mengacu pada parameter 'beyond ecology' yang dapat dilihat pada tabel 2 dan gambar 7 menunjukkan diagram pengaplikasian parameter tersebut pada bangunan yang dirancang.

Tabel 2 Tabel Parameter Beyond Ecology

\begin{tabular}{ll}
\hline Resilience & \multicolumn{1}{c}{ Parameter Beyond Ecology } \\
& $\begin{array}{l}\text { Memiliki ketahanan terhadap perubahan iklim, khususnya pemanasan global } \\
\text { dengan merestorasi terumbu karang melalui sistem biorock (artificial reefs). }\end{array}$ \\
\hline Adaptation & $\begin{array}{l}\text { Dapat beradaptasi dengan kenaikan muka air laut dengan mengangkat } \\
\text { bangunan (sistem panggung) di daratan dan menyatu dengan laut. }\end{array}$ \\
\hline Energy and & Memanfaatkan limbah, air, dan matahari sebagai sumber energi terbarukan \\
Emissions & $\begin{array}{l}\text { (listrik) dari material bangunan (ETFE). Pada bagian bawah bangunan terdapat } \\
\text { sistem pengolahan (waste) menjadi biofuel dan biogas. }\end{array}$ \\
\hline New & $\begin{array}{l}\text { Penerapan biorock pada struktur floating dari bangunan dapat memaksimalkan } \\
\text { Technology }\end{array}$ \\
restorasi terumbu karang. Menerapkan penghisapan sampah melalui bangunan \\
untuk mengurangi sampah di perairan. \\
Digital
\end{tabular}

Sumber: Penulis, 2021 


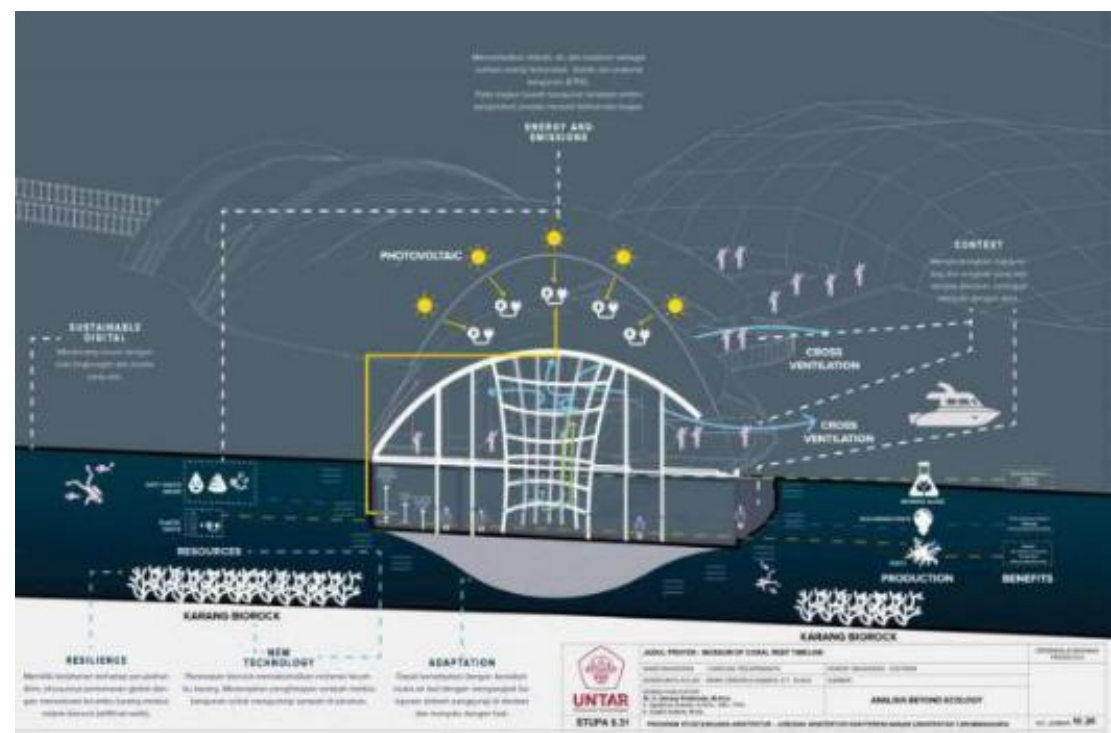

Gambar 7. Diagram Beyond Ecology

Sumber: Penulis, 2021

\section{Hasil Produk Rancangan}

Dari hasil analisis tapak, program, dan bentuk rancangan, dihasilkanlah distribusi program yang dapat dilihat pada gambar 8.

\section{EXPLODED PLAN}

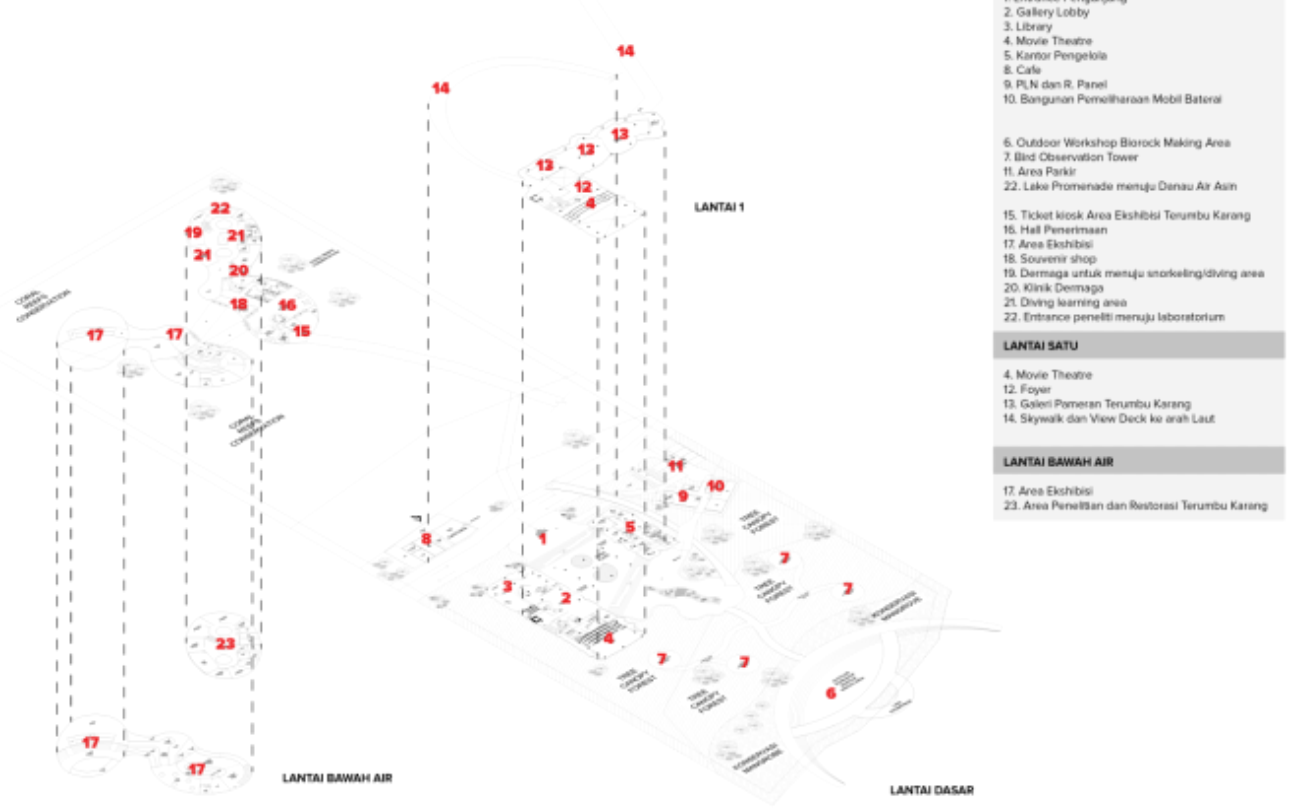

Gambar 8. Exploded Plan

Sumber: Penulis, 2021

Secara keseluruhan, program utama untuk konservasi terumbu karang berada di perairan dengan fasilitas laboratorium untuk pengawasan yang berada di bawah air. Entrance utama dapat diakses dari jalan utama ke arah massa di darat untuk memulai pengalaman perjalanan terumbu karang, kemudian dilanjutkan ke massa di air melalui skywalk tanpa atap. Massa di air dapat diakses juga dari arah pantai melalui dermaga yang terhubung dengan skywalk. Event sequence dari pameran terumbu karang dapat dilihat pada gambar 9 . 

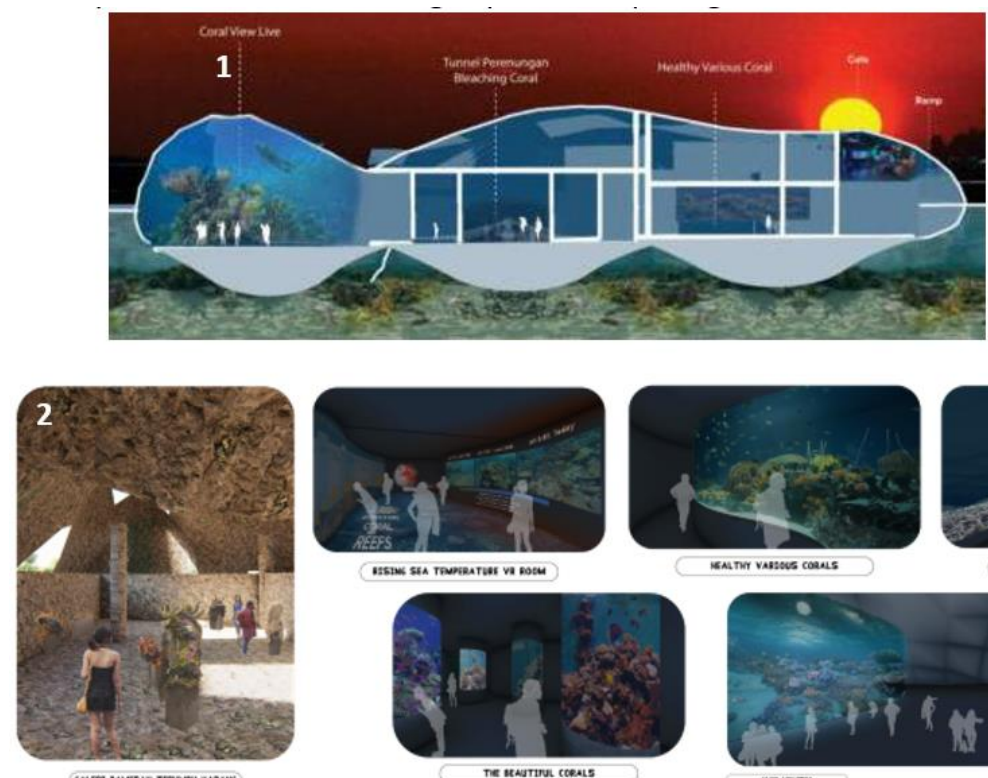

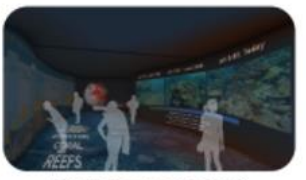

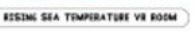

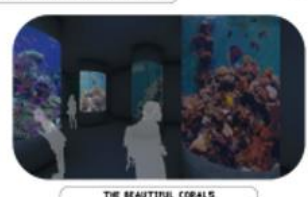

Te revtrun coents

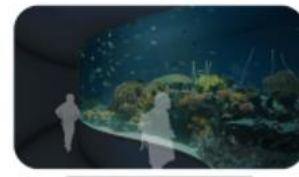

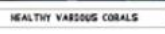

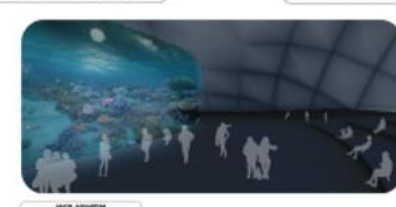

Gambar 9. (1) Potongan Aksonometri Kegiatan Museum Terumbu Karang;

(2) Visualisasi Pameran Perjalanan Waktu Terumbu Karang

Sumber: Penulis, 2021

Struktur yang digunakan pada bangunan di darat terbagi menjadi dua, yaitu interior menggunakan struktur rangka dengan kolom dan balok dan eksterior menggunakan rangka baja ringan dengan finishing batu agar menyerupai bentuk batu karang. Sementara itu, massa di air menggunakan trusses frame dengan penutup ACP dan juga floating structure agar dapat mengapung dan tidak merusak konservasi terumbu karang yang ada di bawahnya, seperti yang dapat dilihat pada gambar 10.

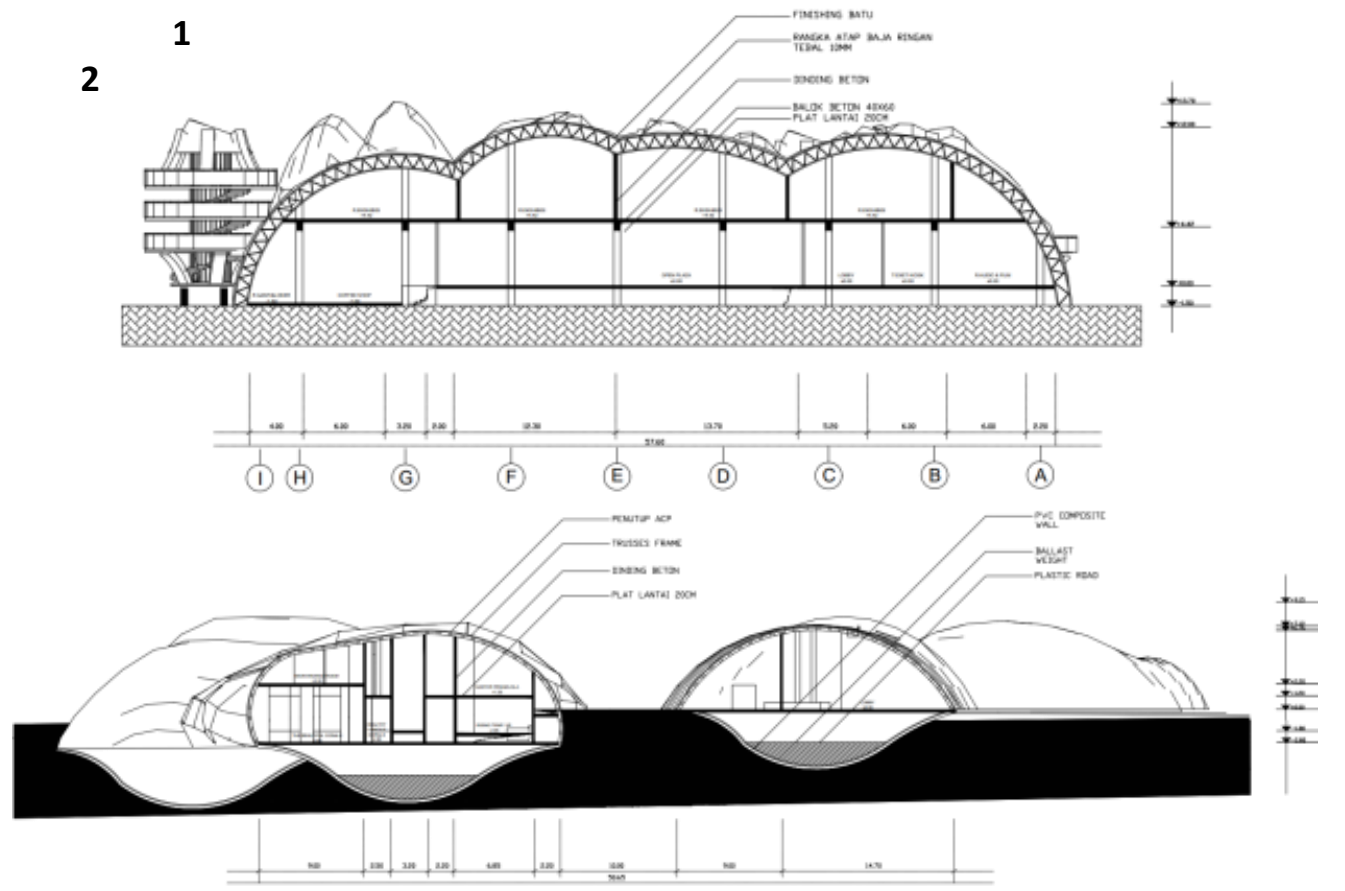

Gambar 10. (1) Struktur Massa Bangunan di Darat;

(2) Struktur Massa Bangunan di Air

Sumber: Penulis, 2021

Proyek tidak terlepas dari lingkungan sekitar yang terkoneksi langsung dengan Danau Air Asin 
dan laut yang kaya akan terumbu karang, serta kawasan pepohonan mangrove (Gambar 11). Tapak dirancang terbuka ke arah danau dengan amphitheater yang dapat digunakan sebagai area workshop biorock atau kegiatan lainnya oleh masyarakat sekitar. Terdapat bird observation tower yang dapat dimanfaatkan pengunjung untuk berinteraksi dengan burung di sekitar proyek rancangan. Pemandangan luas ke arah laut juga dimanfaatkan sebagai view yang baik untuk menyaksikan matahari terbenam.
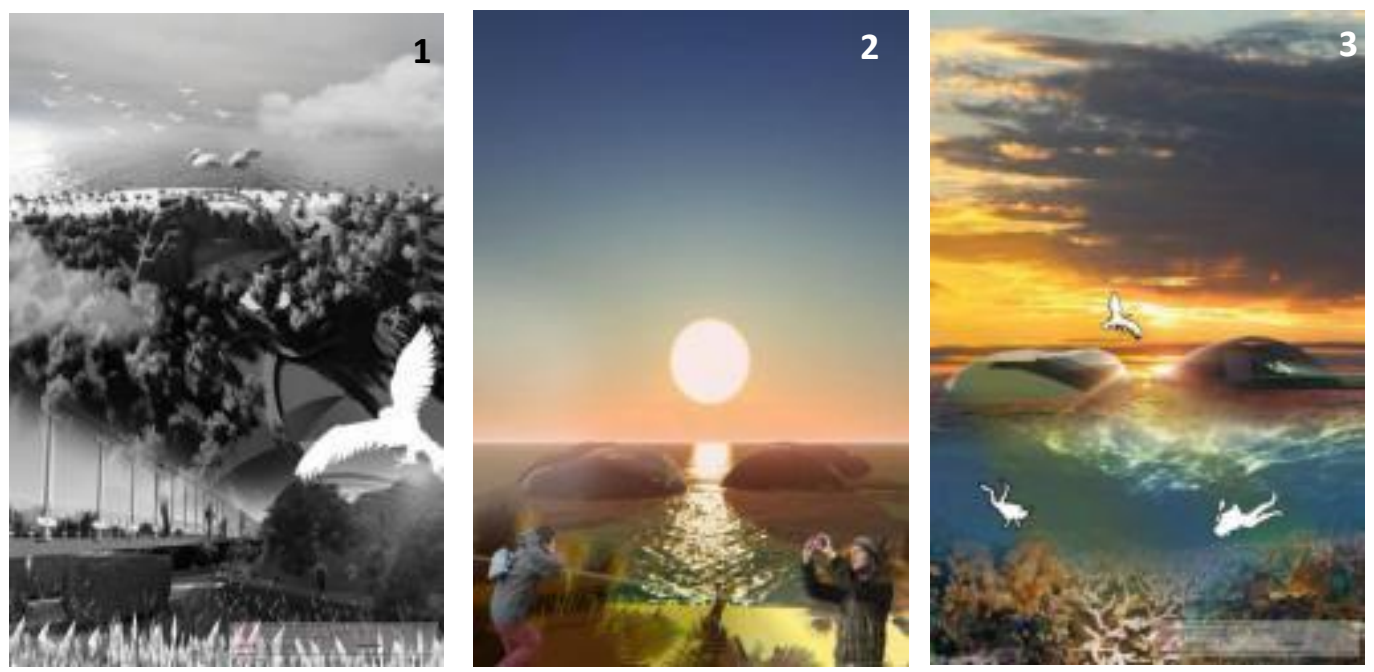

Gambar 11. (1) Kolase perspektif bangunan dengan lingkungan sekitar dan skywalk;

(2) Kolase perspektif mata manusia dengan di saat matahari tenggelam;

(3) Kolase perspektif bangunan dengan konservasi terumbu karang di bawahnya Sumber: Penulis, 2021

\section{KESIMPULAN DAN SARAN}

\section{Kesimpulan}

Proyek Museum Garis Waktu Terumbu Karang yang berada di Gili Meno ini dirancang untuk merespon perubahan iklim, khususnya pemanasan global yang berdampak pada terumbu karang. Kondisi terumbu karang yang semakin buruk akibat kenaikan temperatur air dapat mempengaruhi ekosistem bawah air, yang tidak hanya berdampak pada manusia, melainkan juga biota laut. Melalui program yang diusulkan dan dipadukan sebagai objek wisata, yaitu museum dan kebun karang, serta laboratorium dapat memiliki potensi untuk merestorasi terumbu karang melalui pemeriksaan berkala. Berlokasi di kawasan wisata bahari sangat cocok dengan target pengunjung dari program yang diusulkan, yaitu mengajak kepada masyarakat untuk dapat memelihara terumbu karang, sehingga dapat meningkatkan kesadaran masyarakat dan mempertahankan ekosistem laut, serta dapat memberikan sumbangan atau upaya dalam melestarikan terumbu karang, sekaligus memberikan edukasi kepada masyarakat atau wisatawan untuk mengenal kekayaan terumbu karang di Indonesia.

Proyek ini merupakan titik awal untuk menstimulasi wilayah-wilayah terumbu karang lainnya yang mengalami pemutihan, sehingga dapat mengajak masyarakat untuk memelihara terumbu karang dalam skala nasional, hingga internasional.

\section{Saran}

Proyek ini perlu didukung oleh pemerintah dengan target masyarakat lokal dan mancanegara, serta untuk mendukung pariwisata Indonesia untuk lebih mengenalkan kekayaan terumbu karang di Indonesia. Penyuluhan melalui seminar-seminar juga diperlukan sejak dini, terutama di daerah pesisir untuk lebih mengenalkan peranan terumbu karang terhadap kehidupan yang ada di bumi, sehingga dapat mencegah perilaku-perilaku egois manusia terhadap alam. 


\section{REFERENSI}

Aldrian E, Karmini M, Budiman. (2011). Adaptasi dan Mitigasi Perubahan Iklim di Indonesia. Jakarta: Badan Meteorologi, Klimatologi dan Geofisika (BMKG).

Asriyana, dan Yuliana. (2012). Produktivitas Perairan. Jakarta: PT Bumi Aksara

BMKG, Badan Meteorologi, Klimatologi, dan Geofosika, Ekstrem Perubahan Iklim, diunduh 20 Februari 2021, <https://www.bmkg.go.id/iklim/?p=ekstrem-perubahan-iklim>

Buletin Utama Teknik Vol. 14, No. 2, Januari 2019

Dahuri R, Rais J, Ginting SP, Sitepu MJ. (2001). Sumber Daya Wilayah Pesisir dan Lautan Secara Terpadu. Jakarta: Balai Pustaka.

Dewan Nasional Perubahan Iklim. (2013). Perubahan Iklim dan Tantangan Perubahan Bangsa. Dewan Nasional Perubahan Iklim. Jakarta.

Hadi, G., dkk. (2017). Status Terumbu Karang Indonesia 2018. Jakarta: Pusat Penelitian Oseanografi Lembaga IImu Pengetahuan Indonesia 2018.

Intergovernmental Panel on Climate Change. (2007). Climate Change 2007 - Impacts, Adaptation and Vulnerability. Contribution of Working Group II to the Fourth Assessment Report of the Intergovernmental Panel on Climate Change. Cambridge: Cambridge University Press.

Intergovernmental Panel on Climate Change. (2001). Climate change 2001: Impacts, Adaptation, And Vulnerability: Contribution of Working Group II to the third assessment report of the 74 Intergovernmental Panel on Climate Change. Cambridge: Cambridge University Press.

KKP, Kawasan Konservasi Perairan, Profil TWP. Gili Matra dan Laut Sekitarnya, diunduh 20 Februari 2021, <https://kkp.go.id/djprl/bkkpnkupang/page/2442-profil-twp-gili-matra-danlaut-sekitarnya>

Kementerian Kehutanan Badan Penelitian dan Pengembangan Kehutanan. (2014). Pengarusutamaan Biaya Adaptasi terhadap Perubahan Iklim Dalam Perencanaan Pembangunan. Volume 8 No. 7.

Pena, W. M. (2001). Problem Seeking An Architectural Programming Primer 4th Edition.

Setiawan, F., Muttaqin, A., Tarigan S.A. (2017). Dampak Pemutihan Karang Tahun 2016 Terhadap Ekosistem Terumbu Karang: Studi Kasus Di TWP Gili Matra (Gili Air, Gili Meno dan Gili Trawangan) Provinsi NTB. Jurnal Kelautan Vol.10. No. 2. 2017.

Wahyono, dkk. (2011). Membuat Pupuk Organik Granul dari Aneka Limbah. Jakarta Selatan: PT. Agromedia Pustaka.

Winarno, R. (1992). Ekologi sebagai Dasar untuk Memahami Tatanan dalam Lingkungan Hidup. 29 Desember 1992, Malang, Indonesia.

Zurba, N. (2019). Pengenalan Terumbu Karang, Sebagai Pondasi Utama Laut Kita. Sulawesi: Unimal Press. 